\title{
DOI 10.26886/2520-7474.2(40)2020.5
}

UDC: 159.923:159.942.5

\section{PSYCHOLOGICAL FEATURES OF HUMOR AS A METHOD OF REGULATING EMOTIONAL STATES OF A PERSON IN DIFFERENT PSYCHOTHERAPY SCHOOLS}

\section{Volzhentseva, Doctor of Psihological Sciences, Professor, the Academician of Ukraine Technological Academy (UTA) http://orcid.org/0000-0003-0458-531X} iv.volzhentseva@yandex.ru

Hryhoriy Skovoroda Pereyaslav - Khmelnytskyi State Pedagogical University,

Ukraine, Pereyaslav - Khmelnytskyi

The article provides a theoretical analysis of scientific literature on the problem of emotional states and their regulation. As part of the response levels of states - mental, physiological, behavioral - humor is proposed as a method of gelotology / laughter therapy. The positive impact of humor and laughter on the psychophysiological state of a person, his cognitive and spiritual potential is noted. The structure of the use of humor in the framework of gaming activities is given. The positive psychotherapeutic effect of using gerontology in the regulation of emotional states of the individual in different psychotherapeutic schools is analyzed. The use of humor in psychotherapeutic paradigms and counseling is systematized.

Keywords: humor, gelotology, emotional states, regulation, psychotherapy schools, counseling.

доктор психологических наук, профрессор, академик Украинской технологчческой академии (УТА), Волженцева И. В. Психологические особенности юмора как приема регуляции эмоциональных 
психотерапевтических школах / Переяслав-Хмельницкий государственный педагогический университет имени Григория Сковороды, Украина, Переяслав.

В статье проводится теоретический анализ научной литературы по проблеме эмоциональных состояний и их регуляции. В рамках уровней реагирования состояний - психического, фризиологического, поведенческого - предложен юмор, как прием гелотологии / смехотерапии. Отмечено позитивное воздействие юмора и смеха на психофизиологическое состояние человека, его познавательный, духовный потенциал. Представлена структура использование юмора в рамках игровой деятельности. Проанализирован положительный психотерапевтический эффрект использования гелотологии в регуляции эмоциональных состояний личности разных психотерапевтических школ. Систематизировано применение юмора в психотерапевтических парадигмах и консультировании.

Ключевы слова: юмор, гелотология, эмоциональные состояния, регуляция, психотерапевтические школы, консультирование.

Постановка проблемы. На сегодняшний день в связи с глобальными мировыми изменениями в обществе, политической, экономической нестабильностью, социальной дифференциацией населения, все большую актуальность приобретают проблемы, связанные с сохранением психического здоровья, значительное место в котором занимают эмоциональные состояния. Именно их оптимизация обеспечивает продуктивность деятельности личности, формирование целей и стратегии поведения, которые, в свою очередь, формируют отношение к окружающей действительности, проявляются в суждениях и мотивах действий. Поэтому одной из актуальных 
проблем как психотерапевтами и консультантами, так и клиентами является проблема подбора методов регуляции эмоциональных состояний с учетом пожеланий, особенностей восприятия и влияния, а также индивидуальных особенностей личности.

Исследования П. Малапер, Г. Хейманса и Е. Вирсмы, П. Фресса, Г. Крейга, A. Reber, В. Д. Небылицына, А. Е. Ольшанниковой, О. П. Санниковой, О. А. Орищенко, Ю. Г. Черножук, И. Г. Павловой, И. П. Сопрун посвящены проблеме эмоциональной сферы личности, особенностям ее проявления и регуляции [1].

Так, П. Малапер выделял особый тип эмоциональных людей наряду с апатичными и страстными. Г. Хейманс и Е. Вирсма выделяли три главных фрактора личности: эмоциональность, активность и реактивность [32]. В зарубежной психологии первоначально эмоциональность понималась как эмоциональная возбудимость (отзывчивость человека на эмоциогенные ситуации) и реактивность (реакция человека на раздражители). П.Фресс, например, дал следующее определение эмоциональности: "эмоциональность как черта личности - это чувствительность к эмоциогенным ситуациям" [25]. Эмоциональность как качественную характеристику гиперэмоциональности рассматривает и Г. Крейг [7]. Для нее эмоциональность - это склонность легко поддаваться страху и гневу. В целом, по мнению А. Reber [40], Г. Крейг [7], в современной зарубежной психологии эмоциональность трактуется в терминах актов поведения, которые можно наблюдать и которые теоретически связаны с лежащей в их основе эмоцией, т.е. эмоциональность является поведенческим проявлением, которое считается основным компонентом при оценке испытываемой эмоции.

В отечественной психологии Б. М. Тепловым были выявлены наиболее "сензитивные" к эмоциональному воздействию 
фризиологические показатели и раскрыт характер соотношения между индивидуальным своеобразием физиологических сдвигов при эмоциональных состояниях и некоторыми свойствами нервной системы [24], а развернутое определение эмоциональности как обширного комплекса свойств и качеств, характеризующих особенности возникновения и прекращения разнообразных чувств, афрфектов и настроений, данное В. Д .Небылицыным, явилось логичным продолжением данного научного направления [13]. В качестве основных характеристик эмоциональности он выделил впечатлительность, импульсивность и эмоциональную лабильность. В основу эмоциональности А. Е. Ольшанниковой были положены знак и модальность эмоций. Основываясь на физиологических данных, она первоначально выделила три основные эмоции: удовольствиерадость, гнев и страх [14]. Позднее, в качестве самостоятельной эмоции к этой триаде добавилась печаль. Так, согласно О. П. Санниковой, эмоциональность базируется на четырехкомпонентной теории с выделением уже четырех модальностей: радости, страха, гнева и печали [21; 22].

Как показывает обзор литературы, в отечественной психологии эмоциональность трактуется несколько шире, нежели в зарубежной, в которой эмоциональность рассматривается только со стороны ее динамической характеристики. Другой отличительной чертой отечественной психологии в плане изучения эмоциональности являются успешные попытки выявить влияние эмоциональности на особенности поведения, на эффрективность общения и на другие виды практической деятельности.

Так, О. П. Санникова показала, что широкий круг общения, большая активность общения в сочетании с ее недолговременностью характерны для лиц с положительными эмоциональными установками, 
а узкий круг общения, малая активность общения на фроне устойчивых отношений - для лиц со склонностью к переживанию отрицательных эмоций [21]. М. В. Депенчук выявлено, что лица с высокой эмоциональностью хуже адаптируются в новой социокультурной среде [4], а А. И. Палеем обнаружена связь между качественными особенностями эмоциональности, ее модальной структурой и когнитивным стилем деятельности [15].

Различные методы регуляции эмоциональной сфреры человека рассматривались в исследованиях Г. Ш. Габдреевой, Г. Дикой и Л. П. Гримака, К. Изарда, Н. А. Мартыновой, Ю. Н. Видюк, Т. Б. Кодлубовской, Л. М. Балабановой, А. С. Хромовой и др.

Так, Г. Ш. Габдреева предлагает осуществлять регуляцию психических состояний студентов прямыми и опосредованными методами. К методам прямой регуляции она относит применение психофрармакологических средств, фрукциональной музыки, библиотерапии, а к методам опосредованного влияния на психическое состояние - трудотерапию, имитационные игры и внушение. Имитационные игры Г. Ш. Габдреева предлагает использовать для изменения личностных качеств человека (например, застенчивости). Одним из эфрфективных способов воспитания способности к самоуправлению она предлагает психорегулирующую тренировку (ПРТ) [2].

Для оптимизации психических состояний курсантов в условиях образовательного учреждения пограничного профиля Ю.Н.Видюк предлагает использовать внутренние (психическая саморегуляция) и внешние (музыкальное воздействие и воздействие средствами визуального ряда) методы. К основным методам психической саморегуляции автор относит: аутогенную тренировку; идеомоторную тренировку; сенсорную репродукцию образов; нервно-мышечную 
релаксация, которые позволят курсантам регулировать свои психические состояния вне зависимости от внешних условий [1].

Теоретический анализ научной литературы, эмпирические фракты исследований показали недостаточность разработанности и использования гелотологии в психотерапевтическом процессе.

Цель статьи - проанализировать психотерапевтический эффект использования гелотологии в регуляции эмоциональных состояний и эмоциональных поведенческих проявлений личности в рамках различных теоретических школ.

Изложение основного материала. Достаточно часто в качестве самостоятельного класса выделяют эмоциональные состояния. К этой группе относят большое число состояний, таких как настроения, афрфекты, эйфория, тревога, фрустрация, стресс и др. Данная группа отличается значительным пересечением с различными другими классификационными группами: гностическими, волевыми и др. Такая особенность объясняется тем, что среди любых других состояний мы не сможем найти ни одного, для которого эмоциональные характеристики не имели бы значения и их не стоило бы включать в его описание. В.Н.Мясищев эмоциональные состояния выделял как отдельную группу эмоциональных явлений, как область чувств (эмоций), охватывающую три разнородные группы явлений эмоциональные реакции, эмоциональные состояния и эмоциональные отношения [12].

Эмоции и состояния неразрывно связаны. И те и другие имеют интегративные функции и обеспечивают реагирование человека как целостности (в его духовном, психическом и телесном единстве) на текущую ситуацию, на все воздействия, направленные на него. Любое состояние включает в себя определенные эмоции как неотъемлемую составляющую. 
Эмоциональные состояния - это класс состояний, в которых эмоциональные характеристики выходят на передний план. Возникая, психические состояния могут как положительно влиять на исполнительскую деятельность (трудовую, учебную, спортивную), на процесс общения, так и дезорганизовать их, то есть могут выполнять регулирующее влияние; возникновение того или иного состояния связано, прежде всего, с изменением прогнозов относительно выполняемой деятельности (качества, результата, эффективности). Эмоциональное состояние - это форма реагирования, которая отражает отношение личности к собственным психическим явлениям в некоторый момент времени при определённых условиях. Это целостная характеристика психической деятельности человека, фриксирующая определённый статический момент в психическом. В.А. Семиченко подчёркивает, что состояния фриксируют уже имеющийся результат некоторых переживаемых или вспоминаемых событий, а также степень реагирования (активности) человека [22, 4]. Большинством авторов при рассмотрении эмоциональных состояний выделяются три уровня реагирования: психический (переживание), физиологический (соматика, вегетатика), поведенческий (мотивированное поведение) [5, 344].

В данном контексте, объектом реагирования эмоциональных состояний может быть предложен юмор, как прием гелотологии / смехотерапии, который создаёт позитивное душевное состояние, помогает человеку увидеть и открыть для себя различные нелепости жизни и жизненные ситуации, что нормализует самочувствие (фризическое, эмоциональное, поведенческое), направляет к более высокому уровню разрешения проблемы, увеличивает познавательный потенциал, духовно обогащает [3]. 
Прежде чем проанализировать психотерапевтический эффект использования гелотологии в регуляции эмоциональных состояний личности в контексте различных теоретических школ, уточним понятийный аппарат.

Гелотология (от греческого «gelos» - смех) - наука о смехе, основанная психиатром Уильямом Фрайем (William F. Fry), которая изучает влияние смеха на здоровье человека, зародилась в США в 60X годах XX века в Стэнфордском университете [23]. В официальную медицину метод гелотологии ввел американский журналист Норман Казинс, который вошел в историю, как "человек, рассмешивший смерть”, будучи прикованным к постели, он, по словам врачей, без единого шанса на выздоровление, кардинально изменил свой образ жизни просмотром комедий. Также свой вклад в развитие смехотерапии внесли Михаель Титце (Michael Titze, юмородрама, больничные клоуны), В. Франкл (парадоксальная интенция - терапия «от противного») и др. [6].

О положительном влиянии гелотологии на жизнедеятельность человека говорили фрилософы еще 2000 лет назад. Так, Гиппократ в своих сочинениях, отмечал пользу смеха и рассматривал его как лечебное средство, И. Кант подчеркивал, что «Смеясь, душа становится врачом тела». Писатели и мыслители всего мира и всех времен также обращали внимание на позитивное воздействие смеха на эмоциональное состояние человека. Так, Лев Толстой утверждал, что смех рождает бодрость, а Максим Горький писал, что «умный смех - превосходный возбудитель энергии» [3],

Гелототерапия (юморотерапия, смехотерапия) используется различными специалистами для улучшения понимания клиентом себя, своего поведения, для снятия напряжения. Здесь уместно вспомнить австрийского психоаналитика В.Райха [18], который ввел понятие 
«телесной брони», согласно которому «мышечный панцирь» тормозит свободное выражение эмоций в результате психических травм, получаемых человеком в течение своей жизни. В результате невыраженные эмоции, такие как злость или скорбь, сохраняются в организме. Автор отмечал, что напряженные, натянутые мышцы вредны для тела, а подавленные эмоции вредны для души, что проложило путь для целостного подхода не только к массажной терапии и ее влияния на эмоции [17], но теперь и к гелотологии, к ее релаксирующему механизму воздействия. При смехе у человека работают 80 групп мышц, происходит снятие напряжения, обогащение организма кислородом, выработка эндорфинов, снижение уровня гормонов стресса, также юмор приносит пользу через когнитивные механизмы путем опосредования, изменения и более глубокого отношения к ситуации, укрепление самообладания [16; 23]. Именно юмор - средство преодоления стресса, отвлекаясь, человек подругому смотрит на свою проблему, находит выход из казавшейся безвыходной ситуации.

Психотерапевты и консультанты, рассматривающие различные психологические парадигмы, осмысливают в теоретическом и практическом аспектах роль юмора в психотерапии и консультировании. Так, например, определения юмора содержатся в работах P. Мартина (R. Martin, 1982, 1984, 2003), М. Аргайла. Определение терапевтического юмора предлагается в работах А. Бахелора, А.Хорваса, Л. Франзини, С. Глэддинга и др.

Определение «чистого юмора» предложил С.Л. Рубинштейн, что дает возможность его применения в психотерапии и консультировании. Ученым юмор понимается не как комическое, а как более сложное понятие, в котором за смешным чувствуется что-то позитивное, привлекательное, где смех сочетается с симпатией к тому, 
на что он направляется, где юмор предполагает «принятие мира» со всеми его слабостями и недостатками [19].

М. В. Мусийчук отмечает, что юмор способствует оптимизации эмоционального состояния личности посредством эмоционального отстранения, при котором усиливается объективность восприятия. Гносеологическая специфика юмора состоит в реализации способов познания на основе приёмов остроумия (парадокс, абсурд, метафора, каламбур и др. ) как формы экспликации содержания» [10].

Иную точку зрения представляет В.П.Шейнов, который юмор рассматривает как специфическую игру, которая включает такие компоненты: когнитивный, эмоциональный, поведенческий, исполнительский. Также имеет место и диагностический аспект использования юмора как индикатора в клинической психологии для психопатологии (рис. 1).

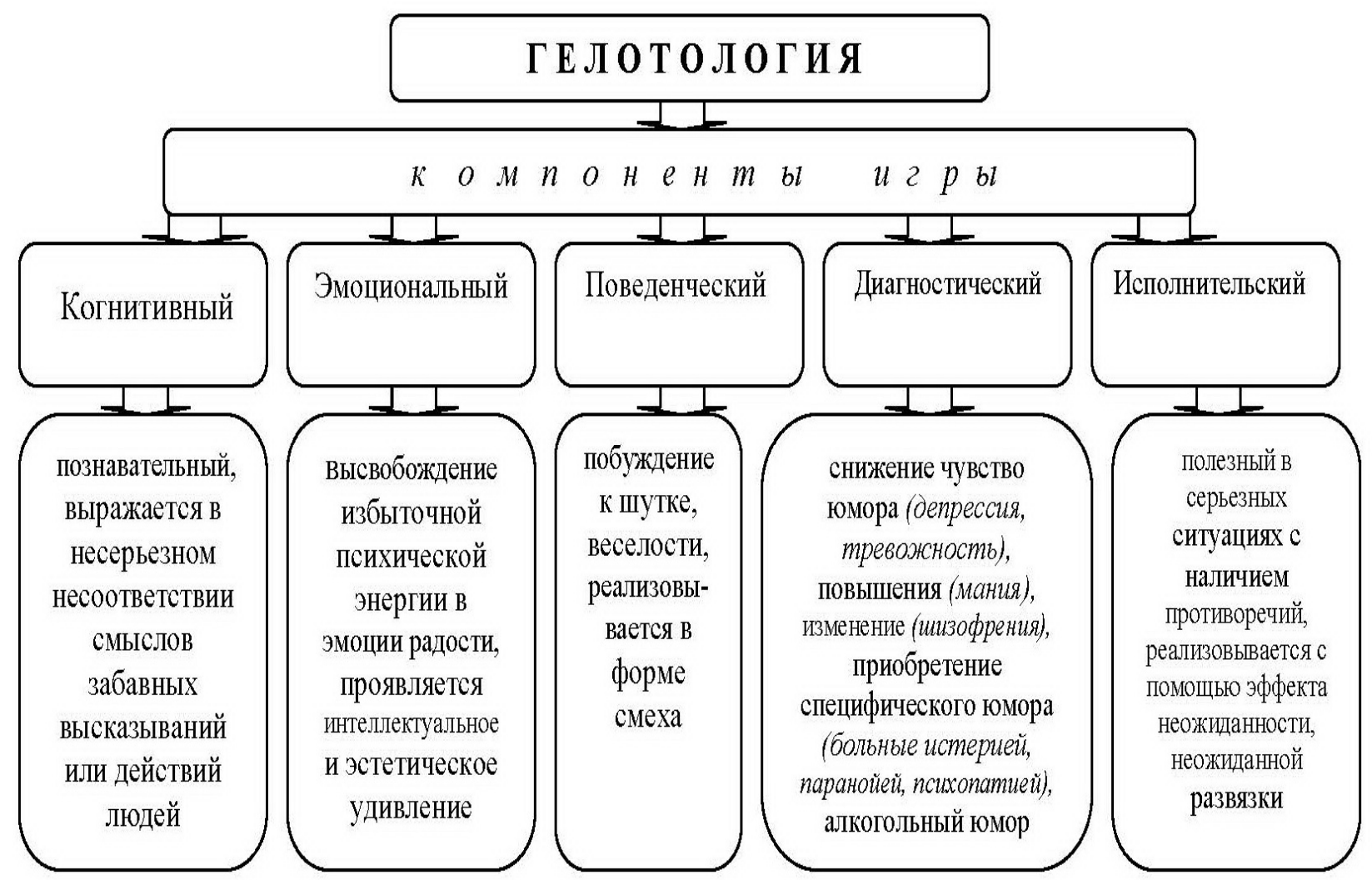

Рис. 1. Структура использование юмора в рамках игровой деятельности 
Так, когнитивный компонент, познавательный, выражается в несерьезном несоответствии смыслов забавных высказываний или действий людей, эмоциональный компонент - высвобождение избыточной психической энергии в эмоции радости проявляется интеллектуальное и эстетическое удивление. Поведенческий компонент выражается в побуждении к шутке, веселости, реализовывается в форме смеха, а исполнительский компонент полезный в серьезных ситуациях с наличием противоречий, реализовывается с помощью эффекта неожиданности, неожиданной развязки. Известен еще диагностический аспект использования юмора как индикатора в клинической психологии для психопатологии. Так, снижение чувства юмора говорит о наличии у респондента депрессии, тревожности, повышение чувства юмора - о мании, а изменение - о шизофрении. Приобретение человеком специфического юмора говорит о наличии больных истерией, паранойей, психопатией, имеет место и алкогольный юмор.

Обобщая передовой позитивный опыт использования гелотологии, можно отметить, что юмор оказывает расслабляющее воздействие, положительно влияет на настроение, активизирует эмоции и гормон радости, вытесняет деструктивные психические состояния, повышает творческую активность, развивает уверенность в себе и чувство юмора, что подчеркивает возможным и необходимым более детально рассмотреть психотерапевтический эффрект использования юмора различными теоретическими школами, такими как: психоаналитическая, индивидуальной психологии, бихевиоризма, гуманистическая, когнитивная, рационально-эмотивная, провакационная (см. рис. 2).

Рассмотрим исследования роли юмора в психоаналитической психотерапевтической парадигме. Остроумие, комизм, чувство 
юмора подробно описал 3. Фрейд. В качестве единого основания, с точки зрения ученого, выступает экономия психической энергии. Исследователь показывает, что остроумие экономит торможение, комизм - мышление, юмор - чувства. Детальный анализ 3. Фрейда в контексте отличия комического от остроумного, показывает, что комическое не умышленно, остроту создают, комическое находят [11]. Последователи психоаналитической теории продолжили исследование проблем юмора.

Так, М.С. Бергман анализирует проблему применения юмора в психотерапии [26], Л.И. Корб анализирует юмор как инструмент для психоаналитика [34]. Юмор в психоаналитической теории исследует П. Клайн [33, с. 7-12], И. Зверлинг, авторами обсуждалась возможность анализа любимых шуток в диагностических и терапевтических интервью [43].

Чувство юмора в парадигме индивидуальной психологии рассматривается как важная характеристика личности. Эта черта выделяется как доминирующая у друзей и партнеров межличностных отношениях, как средство временной передышки от напряжения, проблем и конфликтов.

Юмор не избавляет от них, но позволяет видеть проблемы более отвлеченно, отстраненно. Юмор особенно действенен, если направлен на самого себя. Так, А.Н. Лук отмечает, что развитое чувство юмора бывает у душевно стойких людей, а также помогает переносить удары судьбы, смягчает падение и неудачи [8].

К. Резерфорд (1994) [41] подчеркивал значительную пользу от применения юмора в индивидуальной психотерапии и консультировании, Р.А. Мартин и Ю.П. Доббин (1988) исследовали влияние чувства юмора на стресс [38]. В исследованиях А.Р. Мартина, А.Н. Койпера, Л.И. Олинже, К.А. Дэнка юмор анализируется 
как средство преодоления дистресса, повышения самооценки и психологического

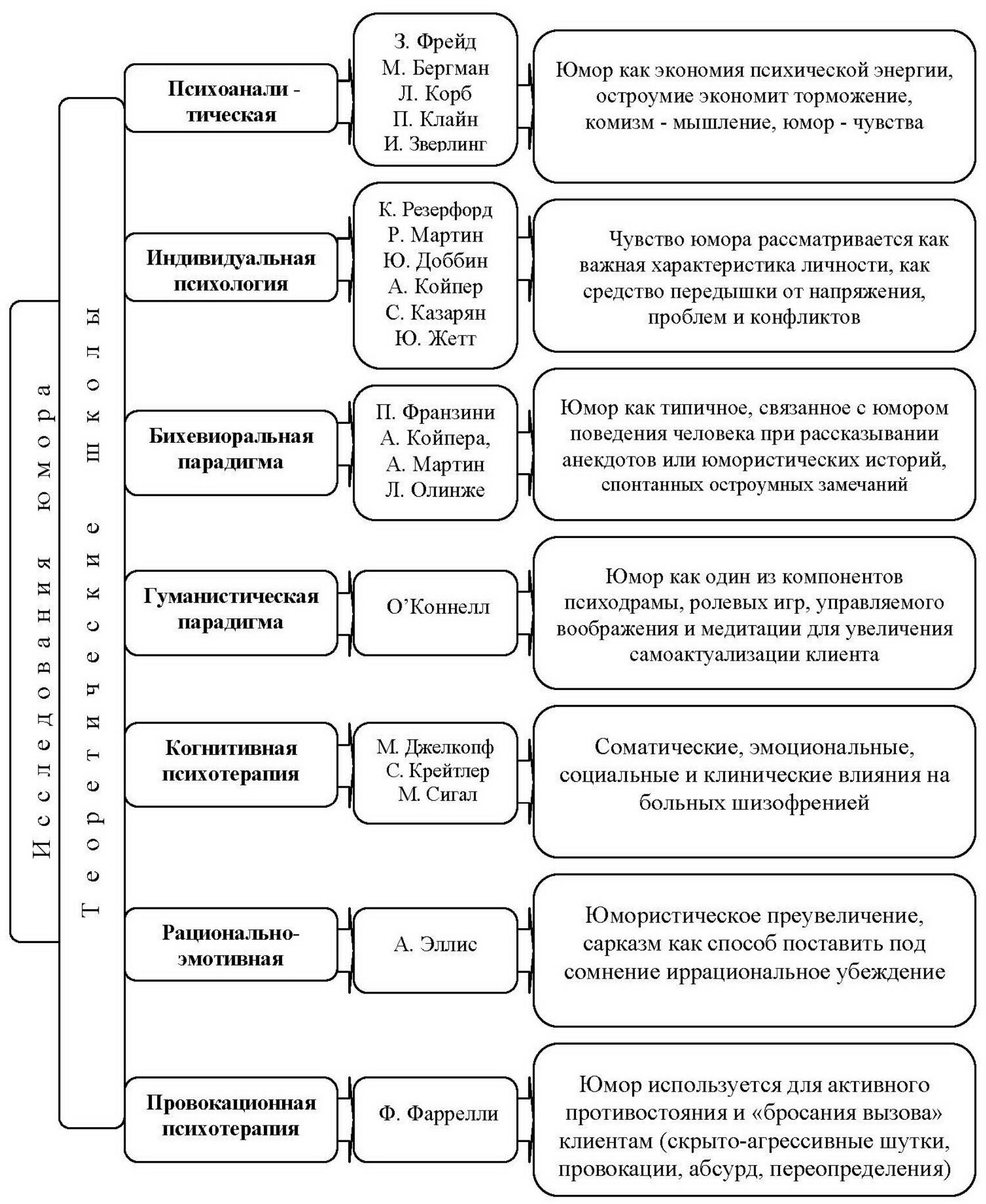

Рис. 2. Применение юмора в психотерапевтических 
благополучия [39]. Индивидуальные различия чувства юмора исследовались $\operatorname{Rim}$ Y. (1988) в связи с различными стилями совладания.

Такие ученые как А.Н. Койпер, С.С. Казарян, Ю.Л. Жетт (1998) сопоставляли чувство юмора, самооценку и психологическое благополучие в психиатрическом стационаре [38].

Чувство юмора в бихевиоральной психотерапевтической парадигме как стиль юмористического поведения проявляется при рассказывании анекдотов или юмористических историй, спонтанных остроумных замечаний, связанных с порождением или восприятием юмора. Понятие чувства юмора в бихевиоральной психотерапии можно рассматривать как типичное, связанное с юмором, поведения человека. В русле современной бихевиоральной терапии проводятся исследования, направленные на изучение юмора в различных социальных ситуациях. Так, П.Л. Франзини [28] исследовал социальный юмор как поведение, W. Ruch, F.-J. Hehl (1987) изучали личностные ценности как облегчающие или сдерживающие процесс восприятия юмора, А.Н. Койпера, А.Р.Мартин, Л.И. Олинже исследовали поведение при использовании копинг-юмора при стрессе [35], R.E. Smith было проведено исследование процесса использования юмора в ответ на гнев [42].

В гуманистической психотерапии здоровое чувство юмора рассматривается как определяющая характеристика самоактуализации. В этом направлении высказывал свою точку зрения и А. Маслоу [9]. Цель гуманистической психотерапии состоит именно в том, чтобы увеличить самоактуализацию клиента, помогая ему перейти от зависимости от окружения и внутренней импульсивности к здоровому ощущению автономии, которое основано на высокой самооценке и удовлетворенности отношениями с другими. 
Для этого гуманистической психотерапией применяются разнообразные методы, такие как психодрама, ролевые игры, управляемое воображение и медитация. Юмор же является одним из компонентов данных методов. С точки зрения О’Коннелл (1981) именно гелотология (юморотерапия, смехотерапия) рассматривается как «самый легкий путь к самоактуализации». Также О’Коннелл отводит главную роль ни клиенту, а психотерапевту. С точки зрения автора именно психотерапевт должен моделировать юмористическую точку зрения клиента и поощрять любой юмор, который спонтанно возникает у него.

В когнитивной психотерапии в использовании юмора прослеживается выделение эмоциональной составляющей и мастерства психотерапевта при его использовании. Такие авторы, как М. Джелкопф, С. Крейтлер, М. Сигал $(1993,1995,1996)$ представили результаты своих исследований в психиатрическом отделении и описали соматические, эмоциональные, социальные и клинические влияния на больных шизофренией. Авторы отмечают враждебность, гнев и юмор как копинг-стратегию больных шизофренией [29].

Широко применяет юмор (юмористическое преувеличение, сарказм как способ поставить под сомнение иррациональное убеждение) в рационально-эмотивной терапии (РЭТ), которую разработал Альберт Эллис [31]. В соответствии с этим подходом психические расстройства развиваются у людей вследствие наличия дисфункциональных установок и нереалистичных абсолютных стандартов. Поэтому, цель рационально-эмотивной психотерапии состоит в том, чтобы пересмотреть и обсудить ложные убеждения клиентов и заменить их более реалистическими и адаптивными допущениями и установками. Эллис (1977) писал, что «психические расстройства у людей в значительной степени заключаются в 
преувеличении значения или серьезности определенных событий и устранение таких преувеличений с помощью юмористического контрпреувеличения вполне может оказаться одной из основных психотерапевтических методик» [30].

Основоположник рационально-эмотивной терапии Альберт Эллис отмечал, что юмор является не только способом поставить под сомнение иррациональные предположения клиентов, но он также полезен в психотерапии, поскольку приносит удовольствие и радость, делает жизнь более интересной и предоставляет альтернативные способы решения проблем.

Теперь перейдем к рассмотрению провокационной терапии. Провокационная (провокативная) терапия разработана Ф. Фаррелли [27], где юмор (скрыто-агрессивные шутки, провокации, абсурд, переопределения) используется для активного противостояния и «бросания вызова» клиентам, то есть происходит трансформация устойчивых выражений, превращение известных высказываний, клише или пословиц в новые утверждения.

Этот подход рекламировался как полезный метод для решения многих типов психологических проблем, например, хроническая шизофрения. Он основан на допущении, что клиенты могут изменить самоуничижительные паттерны поведения и преодолеть психические нарушения, если они возьмут на себя ответственность за свое поведение. Цель провокационной психотерапии состоит в том, чтобы вызвать эмоциональную реакцию у клиентов, которая приведет к изменениям в их представлениях и действиях. Для этого с помощью юмора в форме преувеличения и сарказма ставятся под сомнение их убеждения, чувства и действия, что заставляет их сопротивляться психотерапевту и, в конечном счете, принимать объективную, 
юмористическую точку зрения на свои дисфункциональные паттерны поведения.

Выводы. Таким образом, в результате теоретического анализа проблемы регуляции состояний, в качестве самостоятельного класса выделяют эмоциональные состояния, которые охватывают три разнородные группы явлений - эмоциональные реакции, эмоциональные состояния и эмоциональные отношения. В рамках уровней реагирования состояний - психического, фризиологического, поведенческого - предложен юмор, как прием гелотологии / смехотерапии. Отмечено позитивное воздействие юмора и смеха на психофизиологическое состояние человека, его познавательный, духовный потенциал. Представлена структура использование юмора в рамках игровой деятельности, которая включает такие компоненты: когнитивный, эмоциональный, поведенческий, исполнительский. Проанализирован положительный психотерапевтический эфффект использования гелотологии в регуляции эмоциональных состояний личности, ее поведения в рамках таких психотерапевтических школ, как: психоаналитическая, индивидуальной психологии, бихевиоризма, гуманистическая, когнитивная, рационально-эмотивная, провакационная. Систематизировано применение юмора в психотерапевтических парадигмах, консультировании. Выявлено, что юмор оказывает не только расслабляющее воздействие, положительно влияет на настроение, активизирует эмоции и гормон радости, повышает творческую активность, но и формирует уверенность в себе, способствует экономии психической энергии, является положительным средством от напряжения, проблем и конфликтов, оказывает соматическое, эмоциональное, социальное и клиническое позитивное влияние, повышает самоактуализацию клиента. 
Перспективами дальнейших исследований является экспериментальное изучение особенностей влияния юмора на эмоциональную сфреру личности как коррекционного средства в стрессогенных ситуациях с учетом возрастных особенностей и различных видов деятельности.

\section{Лumepamypa:}

1. Волженцева И. В. (2011) Теоретический анализ особенностей проявления $и$ регуляции эмоциональной сфреры личности. Психология человека в современном мире. Социальнопсихологические проблемы современной семьи и воспитания: материалы Межд. науч.-практ. конфр. (Москва, 1-2 октября 2011 г.) отв. ред. В. А. Кольцова, Д. В. Гавчук. М., Изд-во СвятоСергиевская правос. богосл. академ. С. 659-661.

2. Габдреева Г. Ш. (1981) Самоуправление психическим состоянием: учеб. пособ. Казань: Казанский ун-т. 63 с.

3. Гелотология - наука о смехе [Электронный ресурс]. URL: http://marina-khan.ru/geotologija-nauka-o-smehe/ (дата обращения: 2019).

4. Депенчук М. В. (2000) Ролевой анализ некоторых берлинских пар в связи с процессом социокультурной адаптации. Ананьевские чтения - 2000: тезисы научно-практической конференции. СПб. С. 240-241.

5. Ильин Е.П. (1978) Теория фуннкциональной системы и психифизиологические состояния. Теория функциональных систем в фризиологии и психологии. АН СССР Инс-т психологии; Редкол. Б.Ф. Ломов и др. М., Наука, 1978. С. $325-346$.

6. Конгресс юмора (2002). Эхо Москвы. 05.05.2002.

7. Крейг Г. (2000) Психология развития. Спб., Питер, с. 279. 
8. Лук А.Н. (1968) О чувстве юмора и остроумии. М. 55 с.

9. Маслоу А. (2000) Философрское, невраждебное чувство юмора. Райгородский Д.Я. Хрестоматия. Психология личности. 2-е изд. дополн. Самара. Т. 1. С. 408.

10. Мусийчук М.В. (2012) Когнитивные механизмы структуры комического: фрилософрско-методологические аспекты: автореф. дис. ... док. фрилософрских наук. Новосибирск, С. 14.

11. Мусийчук М.В. (2017) Юмор в психотерапии и консультировании: проблемы и решения в современных парадигмах. Медицинская психология в России: электрон. науч. журн. Т. 9, № 3(44) [Электронный ресурc]. URL: http://mprj.ru (дата обращения: 2019).

12. Мясищев В.Н. (1960) Основные проблемы и современное состояние психологии отношений человека. Психологическая наука в СССР: Сб. АПН СССР Пнс-т психологии. Ред. Б.Г. Ананьев и др. М. Т. 2. С. 15-25.

13. Небылицин В. Д. (1976) Психологические исследования индивидуальных различий. М., 336 с. 366.

14. Ольшанникова А. Е. (1990) Психология. Словарь под общ. ред. А. В. Петровского, М. Г. Ярошевского. [2-е изд., испр. и доп.]. М., Политиздат. 494 с.

15. Палей А. И. (1982) Модальностная структура эмоциональности и когнитивный стиль. Вопросы психологии. № 1. С. 118-126.

16. Психология юмора (2009) Род Мартин; пер. с англ. под ред. Л. В. Куликова. Москва [и др.]. Питер. 478 с.

17. Райх В. (1999) Анализ личности. М., Ювента, 333 с.

18. Райх В. (2000) Анализ характера. М., Эксмо-Пресс, АпрельПресc. $180 \mathrm{c}$.

19. Рубинштейн С.Л. (1999) Основы общей психологии. СПб. С. 577. 
20. Санникова О. П. (1995) Эмоциональность в структуре личности. Одесса? Хорс. 334 с.

21. Санникова О. П. (1984) Эмоциональность и регуляция активности общения младших школьников. Вопросы психологии. № 3. C. 24- 28.

22. Семиченко В.А. (1998) Психические состояния. К., «Магистр - S». $207 c$.

23. Скутин А. В. (2011) Гелототерапия (смехотерапия) - новая медицинская технология. Сибирский вестник психиатрии и наркологии. № 3. С. 89-93.

24. Теплов Б. М. (1985) Избранные труды: в 2-х т. М., Педагогика, Т. І. $328 \mathrm{c}$.

25. Фресс П. Эмоции (1975) Экспериментальная психология. Вып. V. C. 111-195.

26. Bergmann M.S. (1999) The psychoanalysis of humor and humor in psychoanalysis. Humor and psyche: Psychoanalytic perspectives. edit. by J.W. Barron. Hillsdale, NJ: The Analytic Press, P. 11-30.

27. Farrelly E., Brandsma J. (1974) Provocative therapy. Cupertino, CA: Meta Publications.

28. Franzini L.R. (2000) Humor in behavior therapy. Behavior Therapist. Vol. 23, № 2. P. 25-29.

29. Gelkopf M., Sigal M. (1995) It is not enough to have them laugh: Hostility, anger, and humor-coping in schizophrenic patients. Humor: International Journal of Humor Research. Vol. 8, № 3. P. 273-284.

30. Handbook of rational-emotive therapy. edit. by A. Ellis, R. Grieger. New York, Springer, 1977. Vol. 1.

31. Handbook of rational-emotive therapy. edit. by A. Ellis, R. Grieger. New York, Springer, 1986. Vol. 2. 
32. Heymans G., Wiersma E. D. (1908; 1909) Beitrage zur speziellen Psychology auf Grund einer Messenuntersuchungung. Zeitschrift fur Psychology. P. 414-439.

P. 1-72.

33. Kline P. (1977) The psychoanalytic theory of humor and laughter. It's a funny thing, humor. edit. by A.J. Chapman, H.C. Foot. Oxford: Pergamon Press. P. 7-12.

34. Korb L.J. (1988) Humor: A tool for the psychoanalyst // Issues in Ego Psychology. 1988. Vol. 11, № 2. P. 45-54.

35. Kuiper N.A., Martin R.A., Olinger L.J. (1998) Sense of humor, selfconcept, and psychological well-being in psychiatric inpatients. Humor: International Journal of Humor Research. Vol. 11, № 4. P. 357-381.

36. Kuiper N.A., Martin R.A., Olinger L.J. (1993) Coping humor, stress, and cognitive appraisals. Canadian Journal of Behavioural Science. Vol. 25, № 1. P. 81-96.

37. Manjunath N. K., Telles S. (2004) Spatial and verbal memory test scores following yoga and fine arts camps for school children. Indian J. Physiol. Pharmacol. V. 48, № 3. P. 353-356.

38. Martin R.A., Dobbin J.P. (1988) Sense of humor, hassles, and immunoglobulin A: Evidence for a stress-moderating effect of humor. International Journal of Psychiatry in Medicine. Vol. 18, № 2. P. 93-105.

39. Martin R.A., Kuiper N.A., Olinger L.J. (1993) Humor, coping with stress, self-concept, and psychological well-being. Humor: International Journal of Humor Research. Vol. 5, № 1. P. 89-104.

40. Reber A. (1995) The Penguin Dictionary of Psychology Second edition. № 3. P. 23-24.

41. Rutherford K. (1994) Humor in psychotherapy. Individual Psychology. Vol. 50, № 2. P. 207-222.

42. Smith R.E. (1973) The use of humor in the counterconditioning of anger responses: A case study. Behavior Therapy. Vol. 4, № 4. P. 576-580. 
43. Zwerling I. (1955) The favorite joke in diagnostic and therapeutic interviewing. Psychoanalytic Quarterly. Vol. 24. P. 104-114.

\section{References:}

1. Volzhenceva I. V. (2011) Teoreticheskij analiz osobennostej projavlenija i reguljacii jemocional'noj sfery lichnosti [Theoretical analysis of the manifestation peculiarities and regulation of the emotional sphere of personality] Psihologija cheloveka $v$ sovremennom mire. Social'nopsihologicheskie problemy sovremennoj sem'i i vospitanija: materialy Mezhd. nauch.-prakt. konf. (Moskva, 1-2 oktjabrja 2011 g.). otv. red. V. A. Kol'cova, D. V. Gavchuk. M. Izd-vo Svjato-Sergievskaja pravos. bogosl. akadem. S. 659-661. [in Ukrainian].

2. Gabdreeva G. Sh. (1981) Samoupravlenie psihicheskim sostojaniem [Self-management of a mental state]. ucheb. posob. Kazan'. Kazanskij un-t. 63 s. [in Russian].

3. Gelotologija - nauka o smehe [Gelotology - the science of laughter] [Jelektronnyj resurs]. URL: http://marina-khan.ru/geotologija-nauka-osmehe/ (data obrashhenija: 2019). [in Russian].

4. Depenchuk M. V. (2000) Rolevoj analiz nekotoryh berlinskih par v svjazi $s$ processom sociokul'turnoj adaptacii [Role analysis of some Berlin couples in connection with the process of socio-cultural adaptation] Anan'evskie chtenija - 2000: tezisy nauchno-prakticheskoj konferencii. SPb. S. 240-241. [in Russian].

5. Il'in E.P. (1978) Teorija funkcional'noj sistemy i psihifiziologicheskie sostojanija [Functional system theory and psychophysiological states]. Teorija funkcional'nyh sistem $v$ fiziologii i psihologii /AN SSSR Ins-t psihologii; Redkol.: B.F. Lomov i dr. M.: Nauka, 1978. C. 325 - 346. [in Russian].

6. Kongress jumora (2002) [Congress of humor]. Jeho Moskvy. 05.05.2002. [in Russian]. 
7. Krejg G. (2000) Psihologija razvitija [Developmental psychology] Spb., Piter, 992 s. [in Russian].

8. Luk A.N. (1968) O chuvstve jumora i ostroumii [About a sense of humor and wit] M. 55 s. [in Russian].

9. Maslou A. (2000) Filosofskoe, nevrazhdebnoe chuvstvo jumora [A philosophical, non-judgmental sense of humor]. Rajgorodskij D.Ja. Hrestomatija. Psihologija lichnosti. 2-e izd. dopoln. Samara. T. 1. S. [in Russian].

10. Musijchuk M.V. (2012) Kognitivnye mehanizmy struktury komicheskogo: filosofsko-metodologicheskie aspekty [Cognitive mechanisms of the comical structure: philosophical and methodological aspects] avtoref. dis. dok. filosofskih nauk. Novosibirsk, S. 14. [in Russian].

11. Musijchuk M.V. (2017) Jumor $v$ psihoterapii $i$ konsul'tirovanii: problemy $i$ reshenija $v$ sovremennyh paradigmah [Humor in psychotherapy and counseling: problems and solutions in modern paradigms]. Medicinskaja psihologija v Rossii: jelektron. nauch. zhurn. T. 9, № 3(44) [Jelektronnyj resurs]. URL: http://mprj.ru (data obrashhenija: 2019). [in Russian].

12. Mjasishhev V.N. (1960) Osnovnye problemy $i$ sovremennoe sostojanie psihologii otnoshenij cheloveka [The main problems and current state of the psychology of human relationships]. Psihologicheskaja nauka v SSSR: Sb. APN SSSR Pns-t psihologii / Red. B.G. Anan'ev i dr. M. T. 2. S. 15-25. [in Russian].

13. Nebylicin V. D. (1976) Psihologicheskie issledovanija individual'nyh razlichij [Psychological studies of individual differences] M., 336 s. 366. [in Russian]. 
14. Ol'shannikova A. E. (1990) Psihologija [Psychology] Slovar'. pod obshh. red. A. V. Petrovskogo, M. G. Jaroshevskogo. [2-e izd., ispr. i dop.]. M., Politizdat. 494 s. [in Russian].

15. Palej A. I. (1982) Modal'nostnaja struktura jemocional'nosti i kognitivnyj stil' [Modal structure of emotionality and cognitive style]. Voprosy psihologii.

№ 1. S. 118-126. [in Russian].

16. Psihologija jumora (2009) [Psychology of humor] Rod Martin; per. s angl. pod red. L. V. Kulikova. Moskva [i dr.]. Piter. 478 s. [in Russian].

17. Rajh V. (1999) Analiz lichnosti [Individual analysis] M., Juventa. 333 s. [in Russian].

18. Rajh V. (2000) Analiz haraktera [Character analysis] M., JeksmoPress, Aprel'-Press. 180 s. [in Russian].

19. Rubinshtejn S.L. (1999) Osnovy obshhej psihologii [Fundamentals of general psychology] SPb. S. 577. [in Russian].

20. Sannikova O. P. (1995) Jemocional'nost' $v$ strukture lichnosti [Emotionality in the structure of the personality] Odessa: Hors. $334 \mathrm{~s}$. [in Ukrainian].

21. Sannikova O. P. (1984) Jemocional'nost' i reguljacija aktivnosti obshhenija mladshih shkol'nikov [Emotionality and regulation of communication activity of primary school children]. Voprosy psihologii. № 3. S. 24- 28. [in Ukrainian].

22. Semichenko V.A. (1998) Psihicheskie sostojanija [Mental states] Kyiv «Magistr - S». 207s. [in Ukrainian].

23. Skutin A. V. (2011) Gelototerapija (smehoterapija) - novaja medicinskaja tehnologija [Hematotherapy (laughter therapy) - a new medical technology] Sibirskij vestnik psihiatrii i narkologii. № 3. S. 8993. [in Russian].

24. Teplov B. M. (1985) Izbrannye trudy [Selected works] v 2-h t. M., Pedagogika, T. I. 328 s. [in Russian]. 
25. Fress P. Jemocii (1975) Jeksperimental'naja psihologija [Experimental psychology]. Vyp. V. S. 111-195. [in Russian].

26. Bergmann M.S. (1999) The psychoanalysis of humor and humor in psychoanalysis Humor and psyche: Psychoanalytic perspectives. edit. by J.W. Barron. Hillsdale, NJ: The Analytic Press, P. 11-30. [in English].

27. Farrelly E., Brandsma J. (1974) Provocative therapy. Cupertino, CA. Meta Publications. [in English].

28. Franzini L.R. (2000) Humor in behavior therapy. Behavior Therapist. Vol. 23, № 2. P. 25-29. [in English].

29. Gelkopf M., Sigal M. (1995) It is not enough to have them laugh: Hostility, anger, and humor-coping in schizophrenic patients. Humor: International Journal of Humor Research. Vol. 8, № 3. P. 273-284. [in English].

30. Handbook of rational-emotive therapy. edit. by A. Ellis, R. Grieger. New York: Springer, 1977. Vol. 1. [USA].

31. Handbook of rational-emotive therapy. edit. by A. Ellis, R. Grieger. New York: Springer, 1986. Vol. 2. [USA].

32. Heymans G., Wiersma E. D. (1908; 1909) Beitrage zur speziellen Psychology auf Grund einer Messenuntersuchungung. Zeitschrift fur Psychology. P. 414-439. P. 1-72. [in English].

33. Kline P. (1977) The psychoanalytic theory of humor and laughter. It's a funny thing, humor. edit. by A.J. Chapman, H.C. Foot. Oxford, Pergamon Press. P. 7-12. [in English].

34. Korb L.J. (1988) Humor: A tool for the psychoanalyst. Issues in Ego Psychology. 1988. Vol. 11, № 2. P. 45-54. [in English].

35. Kuiper N.A., Martin R.A., Olinger L.J. (1998) Sense of humor, selfconcept, and psychological well-being in psychiatric inpatients. Humor. 
International Journal of Humor Research. Vol. 11, № 4. P. 357-381. [in English].

36. Kuiper N.A., Martin R.A., Olinger L.J. (1993) Coping humor, stress, and cognitive appraisals. Canadian Journal of Behavioural Science. Vol. 25, № 1. P. 81-96. [in English].

37. Manjunath N. K., Telles S. (2004) Spatial and verbal memory test scores following yoga and fine arts camps for school children. Indian J. Physiol. Pharmacol. V. 48, № 3. P. 353-356. [in English].

38. Martin R.A., Dobbin J.P. (1988) Sense of humor, hassles, and immunoglobulin A: Evidence for a stress-moderating effect of humor. International Journal of Psychiatry in Medicine. Vol. 18, № 2. P. 93-105. [in English].

39. Martin R.A., Kuiper N.A., Olinger L.J. (1993) Humor, coping with stress, self-concept, and psychological well-being. Humor: International Journal of Humor Research. Vol. 5, № 1. P. 89-104. [in English].

40. Reber A. (1995) The Penguin Dictionary of Psychology. Second edition. № 3. P. 23-24. [in English].

41. Rutherford K. (1994) Humor in psychotherapy. Individual Psychology. Vol. 50, № 2. P. 207-222. [in English].

42. Smith R.E. (1973) The use of humor in the counterconditioning of anger responses: A case study. Behavior Therapy. Vol. 4, № 4. P. 576580. [in English].

43. Zwerling I. (1955) The favorite joke in diagnostic and therapeutic interviewing. Psychoanalytic Quarterly. Vol. 24. P. 104-114. [in English]. 